\title{
Policy proposal on development of research topics of graduate students at the Faculty of Education, Naresuan University
}

\author{
Thirasak Uppamaiathichai ${ }^{1}$, Passkornr Roueangrong ${ }^{2}$ \\ ${ }^{1}$ Department of Administration and Development, Faculty of Education, Naresuan University, Thailand \\ ${ }^{2}$ Department of Technology and Communications, Faculty of Education, Naresuan University, Thailand
}

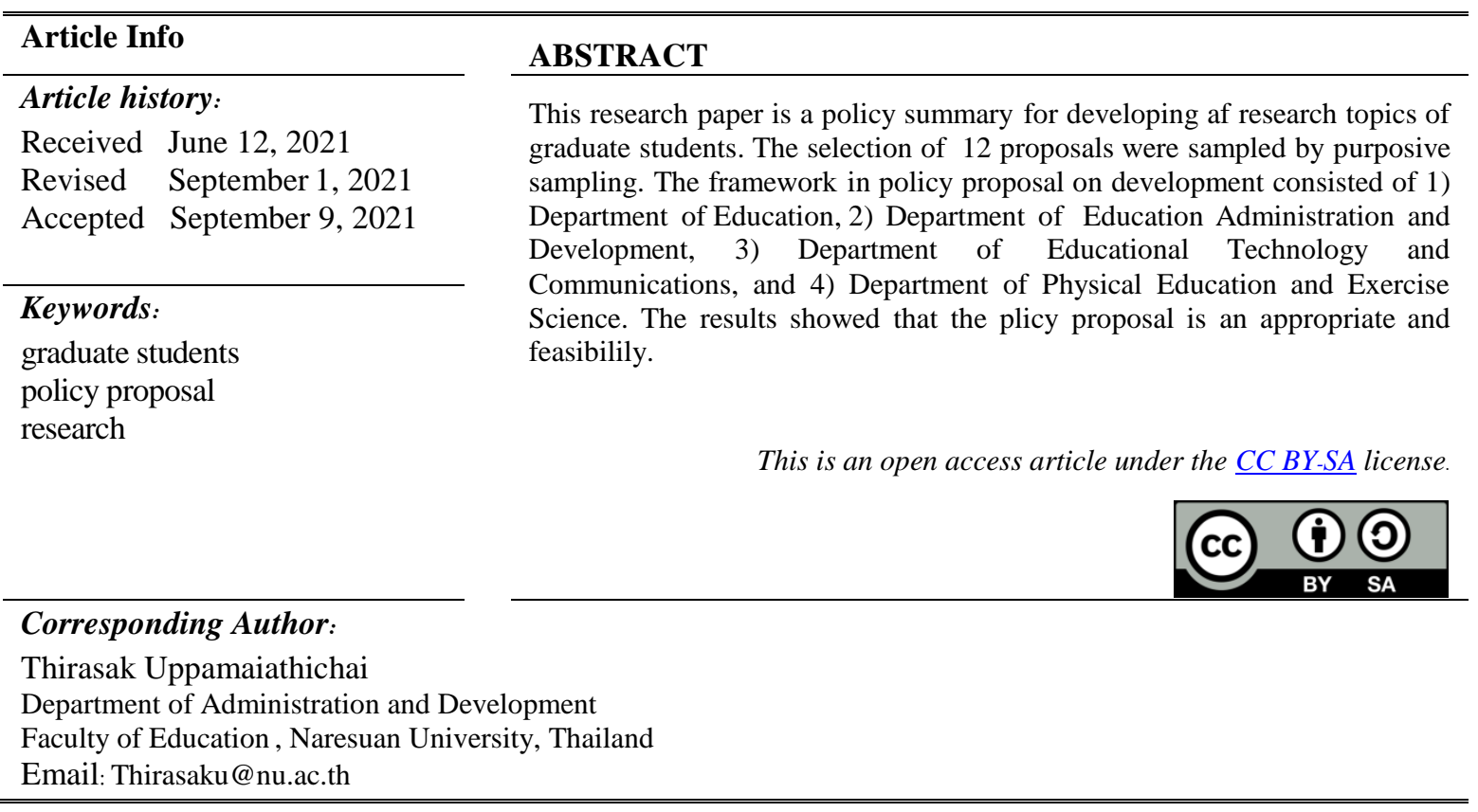

\section{INTRODUCTION}

From the study of the strategic plan to drive the vision, mission, strategy of the Faculty of Education. During the academic year 2020-2023 )Prachanban, 2020(. It was found that strategies under Strategy 1 were to produce quality graduates. Having the ability to be professional and competitive have set a strategy In item 1.1 develop modern curricula and curriculum management system and teaching and learning management. The strategic plan needs of the community, society and countryitem 2.1 to develop and drive a progressive research system and work proactively.2.2 to develop faculty, staff and students to create research and development innovations in education that are actually useful.

In line with the Cabinet's policy statement, in General )Chanocha, 2019(, Prime Minister's statement to the National Assembly Thursday, July 25, 2019. Main policy number 8 in 12 areas, namely reforming the learning process and developing the potential of Thai people of all ages. Innovative research and development issues that respond to the country's development, It is also in line with the strategy in the Phitsanulok Provincial Education Office. In item 2. Development of educational quality and standards; 5. Promotion of manpower production in research and innovation to build competitiveness; and 6. Development of the efficiency of education and management systems.

With a purpose, Creation of an effective and integrated administrative and management system that drives education management by partners cooperation networkAnd to create a link between all sectors in the development of research topics to be related. There are also indicators in various project forms. That have not yet implemented the strategy This causes delays and causes budget outages )Uppamaiathicha \& Roueangrong, 2021: 1441-1447(. For the presentation of this research paper, this research paper is presented in the second step in order to present the policy on the development of research topics among graduate students in the Faculty of Education.

Naresuan University, Thailand is to be concrete and consistent with the current situation, especially the epidemic of COVID-19, the Faculty of Education had to change the strategic plan. We need to adjust teaching and learning management in an online format and greatly improved the communication between learners and graduate teachers.on the topic of research that still needs to be carried out in order to create new knowledge while with data collection or field visits that are difficult to do and may hinder teaching management Therefore, the researcher 
would like to present such a policy form for the benefit of both departments. 4 departments: 1( Department of Education, 2( Department of Education Administration and Development, 3( Department of Educational Technology and Communication, and 4( Department of Physical Education and Exercise Science. This will affect the development of educational management in the next step of development and planning in research of graduate students.

\section{METHOD}

Questionnaire is employed for collecting data from each department. The participants were purposive sampling with 12 experts. Data were collected and analysed by mean and standard deviation using the following interpretation criteria:

$\begin{array}{ll}\text { Mean } & \text { Interpretation } \\ 4.51-5.00 & \text { means it is appropriate and possible at the highest level } \\ 3.51-4.50 & \text { means it is appropriate and feasible at a high level } \\ 2.51-3.50 & \text { means that it is appropriate and feasible at a moderate level } \\ 1.51-2.50 & \text { means that it is appropriate and possible at a low level } \\ 1.00-1.50 & \text { means it is appropriate and feasible at the lowest level }\end{array}$

Analyze the data from the questionnaire, the participants in this research can be listed belows. Mean, Median, and Interquartile range were calculated the difference between the quartiles. If the calculated interquartile range of each statement is 1.50 or less, then the expert opinion on the statement is consistent, and on the other hand, if it is greater than 1.50 , the expert opinion. To the message is inconsistent. The researchers determined the frequency of a score scale of 1 to 5 for each message. The rating scale has the highest frequency is considered a popular base for the message. If any item has the highest frequency of the same score level and the scores are adjacent to each other, for example, Level 3 and Level 4, the middle value between the two scores is taken as the base of the message.

\section{RESULT AND DISCUSSION}

Policy proposal on research topic development of graduate students in the Faculty of Education, Naresuan University within the framework of the departments are 1(Department of Education, 2( Department of Education Administration and Development, 3( Department of Educational Technology and Communication, and 4( Department of Physical Education and Exercise Science. The results showed that is appropriate and feasible with a median of 3.50 and above. In this regard, it shows that the teaching and learning management of the Faculty of Education is well-prepared and up to date. The findings from each department can be shown in Table 1-4.

As demonstrated by academic works, 1( receiving the award for the third-highest research budget in the humanities and social sciences category. At the National Academic Conference, Naresuan Research and Innovation 17th time, 2( participating in the signing ceremony of the Memorandum of Understanding for the School Development Project to enhance the quality of education Supported by the Jai Krating Foundation between the Faculty of Education, Naresuan University Phichit Provincial Education Office Phichit Primary Educational Service Area District Office 2 Phichit Secondary Educational Service Area Office and 4 schools participating in the project, namely Bang Mun Nak School )Rat Uthit( Wat Ban Huai Yao School Ban Noi School "Pruek Uthit" and Wang Takurat Uthit School at the office meeting room, 2nd floor, Phichit Provincial Education Office, 3( on the development of innovative education in civic and cultural functions with the concept of communitybased phenomenal learning consistent with Naresuan University Education Development Plan No. 12 ) 2017-2021(, Revised Edition B.E. 2563-2021, Higher Education Act B.E. 2562 )2019(, 20-Year National Strategy ) 20182037(, the 12th National Economic and Social Development Plan )2017-2021(, the 20-year Long-Term Higher Education Plan 2018-2037, the National Education Plan 2017-2036, policies and Strategies for Higher Education, Science, Research and Innovation B.E. 2020 - 2027, etc. 
Table 1 Department of Education

\begin{tabular}{|c|l|c|c|c|c|c|}
\hline \multicolumn{1}{|c|}{ Item } & Mean & S.D. & median & mode & $\begin{array}{c}\text { Inter } \\
\text { quartile }\end{array}$ \\
\hline 1 & $\begin{array}{l}\text { Article 1.3 there is an integration of life } \\
\text { experience in occupation }\end{array}$ & 4.73 & 0.47 & 5.00 & 5 & 1 \\
\hline 2 & $\begin{array}{l}\text { Item 1.1 should be presented in the form of } \\
\text { curricular management that diversifies the } \\
\text { teaching and learning process in accordance } \\
\text { with 21st century skills. }\end{array}$ & 4.64 & 0.50 & 5.00 & 5 & 1 \\
\hline 3 & $\begin{array}{l}\text { Article 1.5 able to achieve cross-discipline } \\
\text { integration and curriculum to support the } \\
\text { production of manpower and the national } \\
\text { strategy to compete with other countries }\end{array}$ & 4.64 & 0.50 & 5.00 & 5 & 1 \\
\hline 4 & $\begin{array}{l}\text { Article 1.4 can be used for real benefits to } \\
\text { extend the body of knowledge in a holistic } \\
\text { manner }\end{array}$ & 4.45 & 0.52 & 4.00 & 4 & 1 \\
\hline 5 & $\begin{array}{l}\text { Article 1.2 can change the behavior of learners } \\
\text { concretely }\end{array}$ & 4.45 & 0.69 & 5.00 & 5 & 1 \\
\hline
\end{tabular}

Table 2. Department of Educational Administration and Development

\begin{tabular}{|c|l|c|c|c|c|c|}
\hline \multicolumn{2}{|c|}{ Item } & $\bar{X}$ & S.D. & median & mode & $\begin{array}{c}\text { Inter } \\
\text { quartile }\end{array}$ \\
\hline 1 & $\begin{array}{l}\text { Article 1.3 regional policy proposals including } \\
\text { local governments, city councils, city councils, } \\
\text { sub-district municipalities, and schools in the } \\
\text { wilderness }\end{array}$ & 4.82 & 0.40 & 5.00 & 5 & 1 \\
\hline 2 & $\begin{array}{l}\text { Article 1.5 Integration includes having a job } \\
\text { during study and after graduation }\end{array}$ & 4.73 & 0.47 & 5.00 & 5 & 1 \\
\hline 3 & $\begin{array}{l}\text { Article 1.4 research proposing multicultural } \\
\text { differences social angularity integrated research } \\
\text { with various ministries such as the Ministry of } \\
\text { Interior Ministry of Welfare and Human } \\
\text { Security Ministry of Labor Ministry of } \\
\text { Agriculture and Cooperative }\end{array}$ & 4.55 & 0.69 & 5.00 & 5 & 1 \\
\hline 4 & $\begin{array}{l}\text { Article 1.1 should be presented in the form of } \\
\text { policy-based management to drive impacts on } \\
\text { education at a broader national level and local } \\
\text { level }\end{array}$ & 4.45 & 0.52 & 4.00 & 4 & 1 \\
\hline 5 & $\begin{array}{l}\text { Article 1.2 create can enable government } \\
\text { agencies in the form of the Ministry of } \\
\text { Education to actually implement research results }\end{array}$ & 4.45 & 0.52 & 4.00 & 5 & 1 \\
\hline
\end{tabular}

Table 3. Department of Educational Technology and Communication

\begin{tabular}{|c|l|c|c|c|c|c|}
\hline \multicolumn{2}{|c|}{ Item } & $\bar{X}$ & S.D. & median & mode & $\begin{array}{c}\text { Inter } \\
\text { quartile }\end{array}$ \\
\hline 1 & $\begin{array}{l}\text { Article 1.4 Reduction of procedures for } \\
\text { documents, supplies, services, public relations } \\
\text { platform onnecting online teaching and learning } \\
\text { management between institutions This includes } \\
\text { the introduction of innovative productive } \\
\text { research information, textbooks, books or } \\
\text { research articles to support teaching that can be } \\
\text { accessed quickly }\end{array}$ & 4.82 & 0.40 & 5.00 & 5 & 1 \\
\hline 2 & $\begin{array}{l}\text { Item 1.1 should be presented in the form of a } \\
\text { project or a network of cooperation between } \\
\text { educational institutions at the level of basic } \\
\text { education and higher education }\end{array}$ & 4.73 & 0.47 & 5.00 & 5 & 1 \\
\hline
\end{tabular}




\begin{tabular}{|c|l|c|c|c|c|c|}
\hline 3 & $\begin{array}{l}\text { Article 1.2 Establishment of a management } \\
\text { system based on educational technology as a } \\
\text { tool for synthetic analysis of probability. Future } \\
\text { prediction, including the operation in the form } \\
\text { of SWOT }\end{array}$ & 4.55 & 0.69 & 5.00 & 5 & 1 \\
\hline 4 & $\begin{array}{l}\text { Article 1.3 Reduction of procedures for } \\
\text { documents, supplies, services, public relations } \\
\text { platform }\end{array}$ & 4.45 & 0.52 & 4.00 & 4 & 1 \\
\hline
\end{tabular}

Table 4. Department of Technology and Physical Education and Exercise Science

\begin{tabular}{|c|l|c|c|c|c|c|}
\hline \multicolumn{2}{|c|}{ tem } & $\bar{X}$ & S.D. & median & mode & $\begin{array}{c}\text { Inter } \\
\text { quartile }\end{array}$ \\
\hline 1 & $\begin{array}{l}\text { Article 4.1 should be presented in an innovative, } \\
\text { ergonomic form, and can be transferred into the } \\
\text { production technology system }\end{array}$ & 4.73 & 0.47 & 5.00 & 5 & 1 \\
\hline 2 & $\begin{array}{l}\text { Article 4.3 establishment of a system of age } \\
\text { ranges affecting physical activity, including food } \\
\text { that affects health }\end{array}$ & 4.73 & 0.47 & 5.00 & 5 & 1 \\
\hline & $\begin{array}{l}\text { Article 4.4. using the rhythm of music for } \\
\text { movement, therapy, massage, integration with } \\
\text { performing arts, music and dance disciplines, } \\
\text { reflection of national arts and culture and } \\
\text { contemporary traditions }\end{array}$ & 4.73 & 0.47 & 5.00 & 5 & 1 \\
\hline 4 & $\begin{array}{l}\text { Article 4.2 video broadcasting that can be applied } \\
\text { to all ages, including exercise in the elderly }\end{array}$ & 4.64 & 0.67 & 5.00 & 5 & 1 \\
\hline
\end{tabular}

The finding can be summarized that increasing research capabilities, to create innovation for excellence; develop the manufacturing sector and entrepreneur development services and develop economic infrastructure; develop of science, technology, research and innovation; strengthen the core competencies of Thai higher education as a source of development for further knowledge use; create research findings to find answers that will be useful in solving problems and developing the economy at both local and national levels; product and develop of manpower, research and innovation to build the country's competitiveness; the level of productivity )higher productivity( and the ability to compete at the level. The country to be higher )more competitive( with sustainable growth covering all sectors ) more inclusive( Focusing on the use of standards and innovations to develop the country's economy )more sustainable(, reduce economic inequality; reforming the learning process and developing the potential of Thai people of all ages; and prepareg Thai people for the 21st century.

\section{CONCLUSION}

It is in accordance with the Naresuan University Educational Development Plan, Vol. 12 )2017-2021(, the revised edition, 2020-2021, on research focusing on research in order to have research results that create and apply the body of research. New knowledge create innovations or intellectual property that are linked to economic, social, artistic, cultural or environmental conditions. And create a network of cooperation between with government and private organizations both domestically and internationally which focuses on research and innovation results in response to the national strategy needs of society, community, public and private sectors and the country and is useful in the development of teaching and learning. Quality of life or creating value-added opportunities and the country's ability to compete internationally.

\section{ACKNOWLEDGEMENT}

This research was sponsored by Faculty of Education, Naresuan University.

\section{REFERENCES}

Chanocha, P. (2019(. Policy statement of the council of ministers. Bangkok: The Secretariat of the Cabinet.

Higher Education Act. )2019(. Royal Thai Government Gazette. 136(57), 54-78.

Ministry of Higher Education, Science, Research and Innovation. )2020(. Policy and strategy of Minsitry of Higher Education, Science, Research and Innovation 2020-2027. Bangkok: office Committee Science, Research and Innovation.

Naresuan University. (2020). Naresuan University : Education development plan No. 12 (2017-2021) Revised Edition 2020-2021. Division of Planning, Office of the President of Naresuan University.

National Strategy. )2018-2037(. )2018, October 13(. Royal Thai government Gazette. 135 (82), 1-71. 
Office of the Education Council. )2017(. The national scheme of education B.E. 2560-2579 (2017-2036). Bangkok: Ministry of Education.

Office of the Higher Education Commission. )2017(. Higher education plan 2018-2037. Bangkok: Office of the Higher Education Policy and Planning.

Office of the Nation Economic and Social Development Council. )2017(. The twelfth national economic and social development plan )2017-2021(. Bangkok: The Prime Minister's Office.

Prachanban, P. )2020(. Strategic plan academic year 2020-2023. Faculty of Education, Naresuan University.

Uppamaiathicha, T., \& Roueangrong, P. )2021(. The development of research topics of graduate students at the Faculty of Education, Naresuan University. Conference Resilience for Never Normal Era. Naresuan University, 1441-1447. 